\title{
A new species and a new record of the lichen genus Coenogonium (Ostropales: Coenogoniaceae) from South Korea, with a world-wide key to crustose Coenogonium having prothalli
}

\author{
Joshi $\mathrm{Y}^{1 *}$, Gagarina $\mathrm{L}^{2}$, Halda $\mathrm{JP}^{3}, \mathrm{Oh} \mathrm{S-O}^{4}$ and HurJ-S \\ ${ }^{1}$ Lichenology laboratory, Department of Botany, S.S.J. Campus, Kumaun University, Almora - 263601, Uttarakhand, \\ India dryogeshcalo@gmail.com \\ ${ }^{2}$ Laboratory of Lichenology and Bryology, Komarov Botanical Institute Russian Academy of Sciences, St. Petersburg, \\ Russia \\ ${ }^{3}$ Muzeum a galerie Orlických hor, Jiráskova 2, 51601 Rychnov n. Kn., Czech Republic \\ ${ }^{4}$ Korean Lichen Research Institute, Sunchon National University, Suncheon 540-950, South Korea
}

Joshi Y, Gagarina L, Halda JP, Oh S-O, HurJ-S 2015 - A new species and a new record of the lichen genus Coenogonium (Ostropales: Coenogoniaceae) from South Korea, with a world-wide key to crustose Coenogonium having prothalli. Mycosphere 6(6), 667-672, Doi $10.5943 /$ mycosphere/6/6/3

\begin{abstract}
Coenogonium lueckingii, a new corticolous species characterized by a greenish-gray thallus with a white prothallus and 1-septate fusiform ascospores, is described from South Korea. A description of the species is provided together with notes on its chemistry, distribution, ecology and taxonomy. Possible related lichen taxa are discussed briefly, and a worldwide key to the crustose Coenogonium species having a prothallus is also provided. Besides this, Coenogonium pineti is also reported for the first time for the lichen flora of South Korea.
\end{abstract}

Key words - Biodiversity - Chuja Island - Jeju Island - taxonomy

\section{Introduction}

The lichen genus Coenogonium described by Ehrenberg (1820) is represented by more than 80 species worldwide (Ferraro \& Michlig 2013), among which C. luteum (Dicks.) Kalb \& Lücking (2000) is so far known from South Korea (Moon 1999 as Dimerella lutea, Kondratyuk et al. 2013). Coenogonium, which is the only genus in the family Coenogoniaceae (Sitzenberger 1862), is characterized by a crustose or filamentous thallus with a trentepohlioid photobiont, biatorine (rarely zeorine), yellow to orange or brown apothecia with paraplectenchymatous excipulum, sometimes with pilose margins, partially amyloid hymenium, thin-walled unitunicate asci, and generally small, simple to 1-septate ascospores (Rivas-Plata et al. 2006; Lücking 2008).

During a stay in South Korea between 2009-2011, one of the authors (YJ) identified a small specimen of an interesting corticolous species as Biatora sp., which was later rectified as Coenogonium sp. by Sergey Kondratyuk. On a recent field trip to Jeju and Chuja Islands in 2014, additional collections of the same specimen were made by the authors, and all of them were apparently an undescribed Coenogonium species. These specimens are described here as new to science. Besides this, the excursion revealed the occurrence of Coenogonium pineti (Schrad. ex 
Ach.) Lücking \& Lumbsch (Lücking et al. 2004) in South Korea, and that species is hereby reported for the first time as additional record to South Korean lichen flora.

This work is a further contribution to the knowledge of the lichenized fungi of South Korea, which is the result of our current study focusing on the taxonomy and diversity of lichens and allied fungi in that country. The results demonstrate that the biodiversity of crustose lichens is still incompletely known in the region, indicating that further study is warranted.

\section{Materials \& Methods}

The specimens were examined at the Korean Lichen Research Institute, Sunchon National University (KoLRI), using a Motic SMZ-168 stereomicroscope at magnifications of 7.5-50X and an Olympus BX-50 compound microscope at magnifications of 10-1000X. The anatomical features were investigated by preparing sections of thalli and ascomata and then mounting them in water and $10 \% \mathrm{KOH}$. Only free ascopsores lying outside the asci were measured. Images of anatomical and morphological characters were taken using an HD-Measure LTHS-300 (Leetech Co.) microscope connected to a computer. Thin layer chromatography was performed as per Orange et al. (2001).

\section{Results and Discussion}

Coenogonium lueckingii Y. Joshi, Gagarina, Halda \& Hur, sp. nov.

(Fig. 1 a-c) MYCOBANK NO.: MB 815038

Facesoffungi number: FoF 01319

Type: South Korea, Jeju-do province, Seogwipo-si, Donneako valley, Wonang fall, $33^{\circ} 18^{\prime} 04.3^{\prime \prime} \mathrm{N}, 126^{\circ} 34^{\prime} 53.7^{\prime \prime} \mathrm{E}, 330 \mathrm{~m}$, on bark of tree, 19 June 2014, Y. Joshi and party, 140561 (Holotype KoLRI, Isotype BP).

The new species is characterized by a greenish-gray thallus with a white prothallus, apothecia 0.4-0.9 mm diam., with pale yellowish orange to deep orange disc and cream-colored margin, 1-septate spores, $7.5-10 \mu \mathrm{m}$ long and 2-2.5 $\mu \mathrm{m}$ wide.

Thallus corticolous or plasticolous (KoLRI 022458), crustose, continuous, thin, smooth, greenish-gray to pale gray, 30-50 mm diam. (Fig. 1a). Prothallus whitish to silvery gray, shiny, conspicuous (Fig. 1b). Photobiont Trentepohlia, cells rectangular to angular-rounded or globose, in irregular plates or short threads, 5-10 $\mu \mathrm{m}$ diam.

Apothecia single or crowded, sessile with strongly constricted base, biatorine, rounded, rarely slightly irregular in outline, $0.4-0.9 \mathrm{~mm}$ diam., 185-250 $\mu \mathrm{m}$ high; disc cartilaginous, appearing waxy, pale yellowish orange to deep orange, usually slightly translucent, flat to slightly convex. Margin thick, usually distinct, not prominent, rarely evanescent, smooth, cream colored, paler than the disc. Excipulum well developed, paraplectenchymatous with radiating cell rows, colorless, I+ sordid orange-brown 75-125 $\mu \mathrm{m}$; algal cells in basal excipulum. Hypothecium 25-40 $\mu \mathrm{m}$ high, colorless, I-. Hymenium 50-75 $\mu \mathrm{m}$ high, colorless, I+ blue then quickly sordid green then reddish brown, KI+ blue. Paraphyses unbranched, usually with thickened apices 2-4.5 $\mu \mathrm{m}$. Asci cylindrical, completely thin walled without tholus, I-, KI-. Ascospores irregularly biseriate, eight per ascus, ellipsoid to fusiform, transversely 1-septate, colorless, 7.5-10 × 2-2.5 $\mu \mathrm{m}, 3-4$ times as long as broad (Fig. 1c).

Pycnidia not seen.

Chemistry - Thallus and ascomata $\mathrm{K}-, \mathrm{C}-, \mathrm{KC}-, \mathrm{P}-, \mathrm{UV}-$. TLC: no substances detected.

Etymology - The new species is dedicated to Robert Lücking, renowned lichenologist formerly at The Field Museum Chicago, now at the Botanical Garden and Botanical Museum Berlin, for his enormous contributions to the field of lichenology.

Distribution and Ecology - To date, the new species has only been reported from two localities in South Korea, Chuja Island and Mt. Jogye, where it is found growing on the bark of trees in humid habitats. The type locality has a very poor lichen diversity, and the new species was found with fragments of Bacidia sp. and Lecanora sp. 
Notes - The new species is characterized by greenish-gray thallus with a white prothallus, apothecia $0.4-0.9 \mathrm{~mm}$ diam., apothecia with pale yellowish orange to deep orange disc and cream colored margin, 1-septate spores, 7.5-10 $\mu \mathrm{m}$ long and 2-2.5 $\mu \mathrm{m}$ wide. Other known Coenogonium species with prothalli that are either corticolous or foliicolous include: C. albomarginatum Michlig \& L.I. Ferraro (2013), C. atroluteum (Vain.) Lücking, Aptroot \& Sipman (2006), C. kawanae (H. Harada \& Vězda) H. Harada \& Lumbsch (2004), C. magdalenae Rivas Plata, Lücking \& Lizano (2006), C. persistens (Malme) Lücking, Aptroot \& Sipman (2006), C. roumeguerianum (Müll. Arg.) Kalb (2001), C. siquirrense f. siquirrense (Lücking) Lücking (2008), C. siquirrense f. denticulatum Rivas Plata \& Lücking (2006), C. strigosum Rivas Plata, Lücking \& Chavas (2006), C. subsquamosum (Aptroot \& Seaward) Lücking, Aptroot \& Sipman (2006), C. subzonatum (Lücking) Lücking \& Kalb (2001), C. verrucosum Michlig \& L.I. Ferraro (2013) and C. zonatum (Müll. Arg.) Kalb \& Lücking (2000). These taxa are all clearly distinguished from the new species.

Coenogonium subzonatum and $C$. zonatum are strictly foliicolous, contain wart shaped pycnidia, and have smaller apothecia $(0.2-0.5 \mathrm{~mm})$ and uniseriate, relatively broader ascospores. The yellowish gray-green $C$. albomarginatum never has an $\mathrm{I}+$ exciple and the ascospores are uniseriate. Large apothecia $(0.7-1.3 \mathrm{~mm})$ with high hymenia $(70-90 \mu \mathrm{m})$, uniseriate ascospores and neotropical distribution separate $C$. magdalenae from the new taxon. Both $C$. siquirrense $\mathrm{f}$. siquirrense and $C$. siquirrense f. denticulatum differ from the new taxon in having deeply orange apothecia with orange margin. Coenogonium strigosum differs from the new taxon in having a \pm setose thallus, larger apothecia $(0.8-1.5 \mathrm{~mm})$ with a denticulate margin, uniseriate ascospores, and a neotropical distribution. Coenogonium persistens is another neotropical species that differs from the new taxon in having larger apothecia $(0.8-1.5 \mathrm{~mm})$. Coenogonium roumeguerianum differs in having broader spores $(4-6 \mu \mathrm{m})$. The presence of yellow prothalli in $C$. verrucosum and $C$. atroluteum separates them from the new taxon. Coenogonium kawanae differs in having a denticulate margin, uniseriately arranged larger ascospores $(10-14 \mu \mathrm{m})$, while $C$. subsquamosum differs in lacking algal cells in the basal excipulum and having larger apothecia $(0.8-1.2 \mathrm{~mm})$.

When the prothallus is lacking or unclear (poor material, for example), the new taxon looks like $C$. luteum and is often confused with it. However, $C$. luteum differs from it in having much bigger apothecia $(0.8-2 \mathrm{~mm})$, a narrow excipulum $(50-100 \mu \mathrm{m})$ and uniseriately arranged wider spores $(2.5-3.5 \mu \mathrm{m})$.

The new species has a very thick hypothecium $(25-40 \mu \mathrm{m})$ which separates it from two similar species - Coenogonium nepalense and $C$. geralense - both having hypothecium less than 25 $\mu \mathrm{m}$. The hypothecium of $C$. nepalense is $10-13 \mu \mathrm{m}$ and that of $C$. geralense is $10-15 \mu \mathrm{m}$. Besides this, $C$. nepalense and $C$. geralense have not cartilaginous disc of apothecia.

Materials examined - SOUTH KOREA. Jeju-do province: Jeju-si, Hangyeong-myeon,

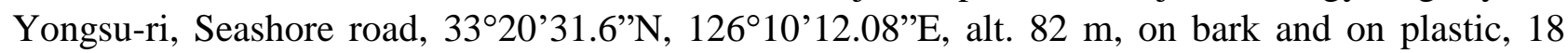
June 2014, J. Halda, 140398 (KoLRI 022458); Jeollanam-do: Sunchon-si, Seungju-eup, Mt. Jogye, Seonam-sa, N3459’33.7” E127²0’22.7”, alt. 210 m, on bark, 2005, L. Lökös, 050679 (KoLRI 003583).

\section{Coenogonium pineti (Schrad. ex Ach.) Lücking \& Lumbsch}

Thallus corticolous, crustose, superficial, continuous, thin, smooth to fine-grained, grayishgreen. Prothallus absent. Photobiont Trentepohlia, cells globose, 6-13 $\mu \mathrm{m}$ diam. Apothecia single or crowded, sessile; 0.1-0.5 mm diam.; disc whitish to pinkish yellow, concave to flat, with concolorous or paler exciple. Excipulum well developed, paraplectenchymatous, 30-110 $\mu \mathrm{m}$. Hypothecium 10-36 $\mu \mathrm{m}$ high, colorless. Hymenium 70-90 $\mu \mathrm{m}$ high, I+ blue then quickly sordid green then reddish brown, KI+ blue. Paraphyses simple, unbranched, with thickened apices to 4 $\mu \mathrm{m}$. Asci numerous, cylindrical, without tholus, I-, KI-. Ascospores uniseriate, eight per ascus, fusiform to ellipsoid, transversely 1-septate, colorless, 9-13 × 2-3(-4) $\mu \mathrm{m}$.

Distribution and Ecology - The species is so far known from Jeju Island where it is found growing on the bark of unknown tree in humid habitat in association with Graphis sp. 

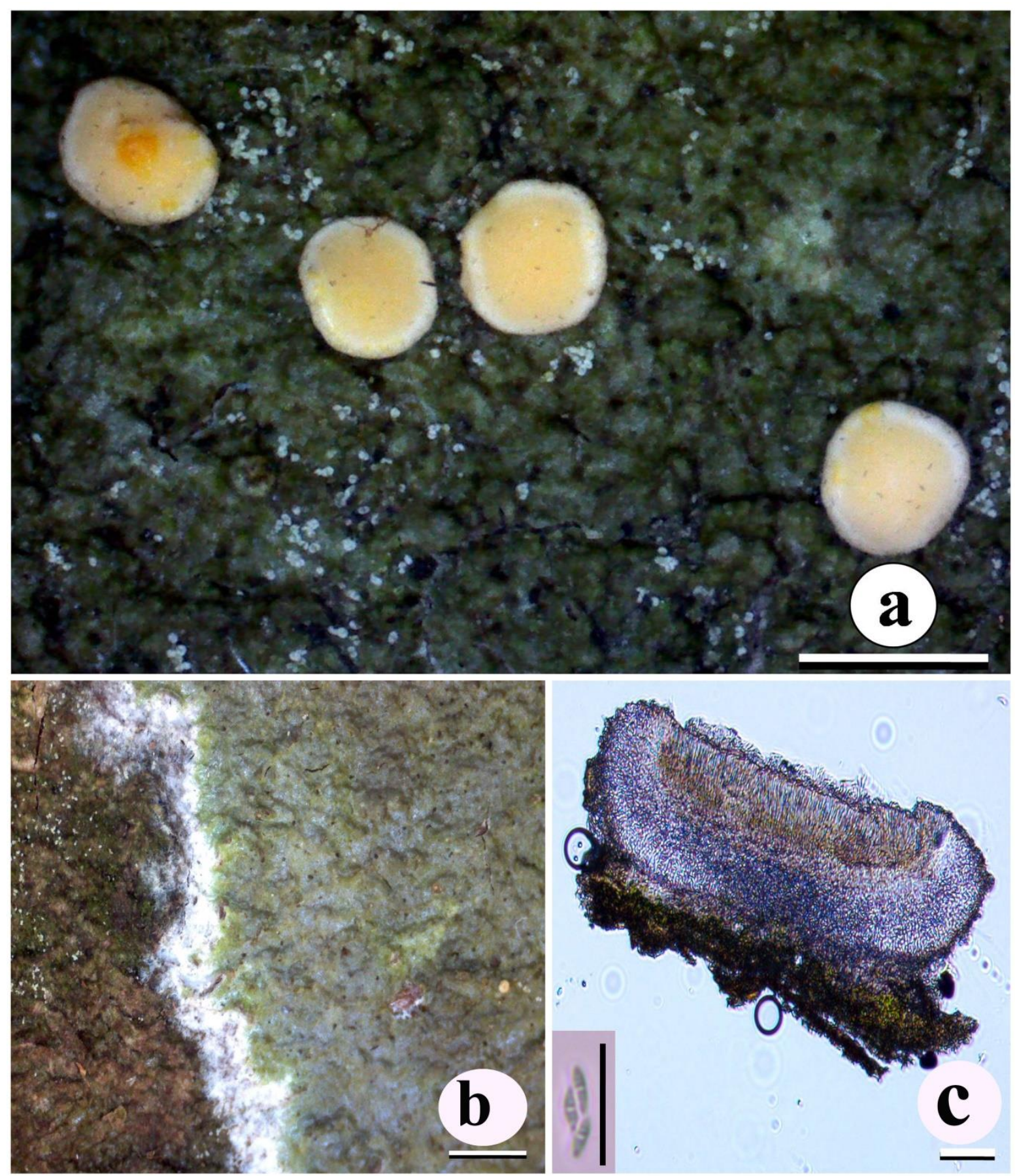

Fig. 1 - Habit of Coenogonium lueckingiii (holotype) a) Thallus (Scale $=2 \mathrm{~mm}$ ); b) Prothallus $($ Scale $=3 \mathrm{~mm}) ; \mathrm{c})$ Transverse section of apothecia along with spores $($ Scale $=100 \& 20 \mu \mathrm{m}$, respectively).

Remarks - Coenogonium pineti is similar to C. dilucidum (Kremp.) Kalb. \& Lücking (2000), C. kawanae and C. luteum. Coenogonium dilucidum differs in having pale wax-colored apothecia and larger ascospores (14-18 $\mu \mathrm{m}$ long), C. kawanae has pale yellow-brownish apothecia and white prothallus, while $C$. luteum has larger $(0.8-2 \mathrm{~mm})$, more bright orange color apothecia and thickened paraphyses up to $4.5 \mu \mathrm{m}$.

Material examined - SOUTH KOREA. Jeju-do province: Seogwipo-si, Donneako valley,

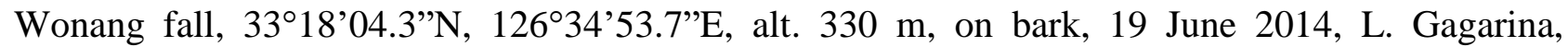
140611 (KoLRI 022470). 


\section{Key to worldwide crustose Coenogonium species having prothalli}

1. Prothallus yellow 2

Prothallus white

2. Thallus verrucose; apothecia orange.

C. verrucosum

Thallus smooth; apothecia pale yellow brown.

C. atroluteum

3. Thallus yellow.

C. subsquamosum

Thallus green-gray

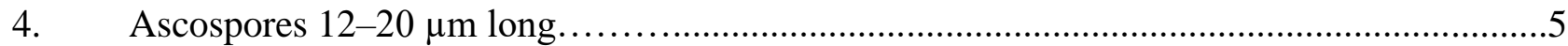

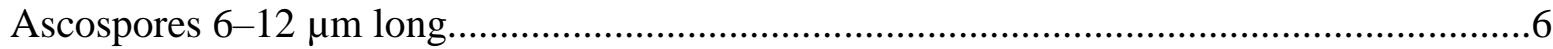

5. Thallus greenish gray; apothecia $0.3-0.5 \mathrm{~mm}$ diam., margin denticulate.

C. kawanae

- $\quad$ Thallus yellow; apothecia $0.8-1.2 \mathrm{~mm}$, margin not denticulate. C. squamosum

6. Ascospores 4-6 $\mu \mathrm{m}$ broad. C. roumeguerianum

Ascospores $1.5-4 \mu \mathrm{m}$ broad

7. Ascospores 3-4 $\mu \mathrm{m}$ broad. ..8

Ascospores $1.5-2.5 \mu \mathrm{m}$ broad.

8. Apothecia medium sized, $0.3-0.8 \mathrm{~mm}$ diameter.

Apothecia large, 0.8-2 $\mathrm{mm}$ diameter.

9. Apothecial margin denticulate; neotropical distribution.

C. subzonatum

Apothecial margin not denticulate; pantropical distribution

C. zonatum

10. Disc orange yellow to orange, thallus sometimes with setae, margin not denticulate............................................................ strigosum Disc pale yellow to yellow, thallus without setae, margin denticulate. ...

C. magdalenae

11. Exciple with very large peripheral cells 12

All cells of the exciple of similar size.

12. Apothecial margin denticulate

C. siquirrense f. denticulatum

Apothecial margin never denticulate

C. strigosum

13. Thallus glabrous, apothecia medium sized $(0.8-1.5 \mathrm{~mm}$ diam.)

C. persistens

Thallus not glabrous, apothecia small sized $(0.4-0.8 \mathrm{~mm}$ diam.

14. Corticolous or plasticolous

C. lueckingii

Strictly foliicolous.

15. Ascospores 8-12 $\mu \mathrm{m}$ long, disc cartilaginous, conidia $13-16 \times 1-1.5 \mu \mathrm{m}$. Palaeotropical distribution. C. pocsii Ascospores 6-9 $\mu \mathrm{m}$ long, disc not cartilaginous, conidia 3-3.5 $\times 1.2-1.5 \mu \mathrm{m}$. Neotropical distribution C. siquirrense f. siquirrense

16. Ascospores 8-12 $\mu \mathrm{m}$ long; thallus without setae. C. persistens Ascospores 6-9 $\mu \mathrm{m}$ long; thallus sometimes with setae. .C. strigosum 


\section{Acknowledgements}

The authors are indebted to Prof. J.-S. Hur for his cordial hospitality in South Korea, to Dr. S.-O. Oh for organizing 2014 excursion to Jeju and Chuja Islands and to Miss. Jeong Shin Park for her help in the field work. This work was supported by a grant from the Korean Forest Service Program (KNA 2014) through the Korea National Arboretum and the Korean National Research Resource Center Program (NRF-2014-M3A9B8002115).

\section{References}

Ferraro LI, Michlig A. - 2013 New species and additional records of Coenogonium (Ostropales: Coenogoniaceae) from southern South America. Lichenologist 45, 497-504.

Harada H, Okamoto T, Yoshimura I. - 2004 A Checklist of Lichens and Lichen-allies of Japan. Lichenology 2, 47-166.

Kondratyuk S, Lőkös L, Tschabanenko S, Haji Moniri M, Farkas E, Wang XY, Oh S-O, Hur J-S. 2013 New and noteworthy lichen forming fungi and lichenicolous fungi. Acta Botanica Hungarica 55, 275-349.

Lücking R. - 2008 Foliicolous lichenized fungi. Flora Neotropica Monograph 103, 1-866.

Lücking R, Kalb K. - 2000 Foliikole Flechten aus Brasilien (vornehmlich Amazonien), inklusive einer Checkliste und Bemerkungen zu Coenogonium und Dimerella (Gyalectaceae). Botanische Jahrbücher für Systematik Pflanzengeschichte und Pflanzengeographie 122, 161.

Lücking R, Kalb K. - 2001 New Caledonia, foliicolous lichens and island biogeography. Bibliotheca Lichenologica 78, 247-274.

Lücking R, Stuart BL, Lumbsch HT. - 2004 Phylogenetic relationships of Gomphillaceae and Asterothyriaceae: evidence from a combined Bayesian analysis of nuclear and mitochondrial sequences. Mycologia 96, 283-294.

Moon KH. - 1999 Lichens of Mt. Sorak in Korea. Journal of the Hattori Botanical Laboratory 86, $187-220$.

Nees von Esenbeck CDG. - 1820 Horae Physicae Berolinenses. 1820, 1-120.

Orange A, James PW, White FJ. - 2001 Microchemical methods for the identification of lichens. British Lichen Society, London, $101 \mathrm{pp}$.

Rivas Plata E, Lücking R, Aptroot A, Sipman HJM, Chaves JL, Umana L, Lizano D. - 2006 A first assessment of the Ticolichen biodiversity inventory in Costa Rica: The genus Coenogonium (Ostropales: Coenogoniaceae), with a world-wide key and checklist and a phenotype-based cladistic analysis. Fungal Diversity 23, 255-321.

Stizenberger E. - 1862 Beitrag zur Flechtensystematik. Bericht über die Tätigkeit der St. Gallischen Naturwissenschaftlichen Gesellschaft 1861-1862, 124-182. 